\title{
Weed Control, Environmental Impact and Profitability of Two-Pass Weed Management Strategies in Glyphosate-Resistant Corn
}

\author{
N. Soltani ${ }^{1, *}$, R.E. Nurse ${ }^{2}$, C. L. Gillard ${ }^{1}$ and P.H. Sikkema ${ }^{1}$ \\ ${ }^{1}$ University of Guelph Ridgetown Campus, Ridgetown, Ontario, NOP 2C0, Canada; ${ }^{2}$ Agriculture and Agri-Food \\ Canada, Harrow, Ontario, NOR 1G0, Canada
}

\begin{abstract}
Twelve field trials were conducted over a three-year period $(2010,2011,2012)$ at different locations in southwestern Ontario, Canada to compare various two-pass weed management strategies in glyphosate-resistant corn for crop injury, weed control, environmental impact, corn yield and profit margin. No visible injury resulted from the herbicide treatments evaluated. One early postemergence (EPOST) application of glyphosate provided good full season control of pigweed species and lady's thumb and fair control of velvetleaf, common ragweed, lamb's-quarters, barnyard grass and green foxtail. One late postemergence (LPOST) application of glyphosate provided excellent control of all weed species evaluated but corn yield was reduced due to early weed interference. The sequential application of glyphosate (EPOST $f b$ LPOST) provided excellent control of all weed species evaluated with no adverse effect on corn yield. The sequential application of a preemergence residual herbicide followed by an application of glyphosate LPOST provided excellent full season control of all weed species evaluated and corn yield was equal to the weed free control. Among the sequential herbicide programs the lowest environmental impact was glyphosate EPOST $f b$ LPOST and saflufenacil/dimethenamid-p, isoxaflutole + atrazine or rimsulfuron + s-metolachlor + dicamba applied PRE fb glyphosate LPOST. Based on this study, the most efficacious and profitable weed management programs in glyphosate-resistant corn are a sequential application of glyphosate or a two-pass program of a preemergence residual herbicide followed by glyphosate LPOST. The two-pass programs have glyphosate stewardship benefits.
\end{abstract}

Keywords: Environmental impact quotient (EIQ), glyphosate, profit margin, corn.

\section{INTRODUCTION}

Corn (Zea mays L.) is important for agriculture and the economy of Ontario. In 2011, 7.2 million tonnes of grain corn was produced on approximately 822,000 hectares compromising nearly $63 \%$ of Canada's total corn production with a farm-gate value of $\$ 1.3$ billion and ranks as the largest annually tilled field crop grown in Ontario [1,2]. Most of the corn grown in Ontario is glyphosate-resistant which has provided growers with additional weed management options with economic advantages [3,4]. Glyphosate-resistant corn was first introduced in Canada in 2001 and the market share has increased steadily over the years. In 2012 , about $94 \%$ of the corn hectares in Eastern Canada were planted to glyphosate-resistant hybrids and the percentage is expected to increase in the future [4].

There are different weed management strategies that can be utilized in glyphosate-resistant corn. These include one application of glyphosate applied early (EPOST) or late postemergence (LPOST), a sequential application of glyphosate applied EPOST and LPOST, an EPOST tankmix application with glyphosate, and a sequential application of a preemergence (PRE) residual herbicide followed by glyphosate applied LPOST [5-8]. Relying exclusively on glyphosate for weed management may result in the selection of

\footnotetext{
*Address correspondence to this author at the University of Guelph Ridgetown Campus, Ridgetown, Ontario, NOP 2C0, Canada; Tel: 519-674-1500; Fax: 519-674-1600; E-mail: soltanin@uoguelph.ca
}

glyphosate resistant weed biotypes [8-10]. Selection pressure can be reduced with tankmixes or sequential applications that utilize more than one herbicide mode of action [8].

Nelson [11] found that yield was maximized when glyphosate was applied before weeds were $10 \mathrm{~cm}$ in height. Other studies have shown that a single-pass herbicide program with no residual activity can result in weed escapes and does not adequately control late emerging weeds [6,12-16]. Sequential in-crop applications of glyphosate or including a PRE residual herbicide followed by glyphosate applied LPOST herbicides have been shown to provide improved weed control in corn [5,6,15,17-19].

The demand on growers to economically produce environmentally sustainable food while maintaining herbicide stewardship is increasing [20]. To achieve this goal, data on weed control, crop yield, economics and environmental impact of herbicides are needed to help identify the most advantageous herbicide program. The environmental impact (EI) of different weed control strategies should be considered when making weed management decisions. The EI of weed management may be reduced by using lower herbicide application rates and/or safer products. The EIQ uses three risk components: farm worker, consumer, and environment to estimate the relative potential risk of pesticide active ingredients [21-23]. The EI of a particular pesticide treatment is obtained by multiplying the EIQ by the application rate. Thus, a higher EI indicates a greater risk of detrimental impact. The EIQ was designed to provide growers and weed 
management practitioners with a single number that indicates the magnitude of relative risk. The EIQ has been used effectively to compare environmental risk of different pesticides and/or production systems [24-28]. The EIQ can be used as a decision tool, along with herbicide efficacy, crop safety, and profit margins to identify the most advantageous weed management strategy in corn.

Research has shown that for any weed management program to succeed growers must consistently get acceptable weed control and an increase in profitability for them to implement these weed management techniques. The viability for various weed management programs needs to be assessed based on profit margins over weed control costs. Limited information exists on the weed control efficacy, corn yield, environmental impact, and profitability of two-pass weed control strategies in corn of a PRE residual herbicide followed by glyphosate applied LPOST in glyphosate-resistant corn under Ontario environmental conditions. Therefore, the objectives of this study were to determine the level of weed control, yield, net returns, and environmental impact of various PRE/POST programs in glyphosate-resistant corn.

\section{MATERIALS AND METHODS}

A total of twelve field trials were conducted in southwestern Ontario at the Greenhouse and Processing Crops Research Centre, Agriculture and Agri-Food Canada, Harrow, at the Huron Research Station, Exeter, Ontario and at the University of Guelph, Ridgetown Campus, Ridgetown, Ontario during 2010, 2011 and 2012. The soils ranged from Fox sandy loam to Brookston clay loam with $33-82 \%$ sand, $5-41 \%$ silt, $15-29 \%$ clay, $12-33 \%$ organic matter and $\mathrm{pH}$ of 6.0-7.9. Site preparation included moldboard plowing or disking in the autumn followed by two passes with a field cultivator in the spring.

Experiments were arranged in a randomized complete block design with four replicates. There were a total of sixteen treatments: 1. Weedy; 2. Weed-free; 3. Glyphosate (EPOST); 4. Glyphosate (LPOST); 5. Glyphosate fb glyphosate (EPOST fb LPOST); 6. Dicamba/atrazine fb glyphosate (PRE fb LPOST); 7. Pendimethalin + atrazine fb glyphosate (PRE fb LPOST); 8. Pendimethalin + dicamba/atrazine $\mathrm{fb}$ glyphosate (PRE fb LPOST); 9. Saflufenacil/dimethenamid$\mathrm{p}$ fb glyphosate (PRE fb LPOST); 10. Isoxaflutole + atrazine fb glyphosate (PRE fb LPOST); 11. S-metolachlor/atrazine + flumetsulam fb glyphosate (PRE fb LPOST); 12. Smetolachlor + flumetsulam + clopyralid fb glyphosate (PRE $\mathrm{fb}$ LPOST); 13. Rimsulfuron + s-metolachlor + dicamba $\mathrm{fb}$ glyphosate (PRE fb LPOST); 14. Atrazine fb glyphosate; 15. S-metolachlor/atrazine fb glyphosate (PRE fb LPOST); and 16. S-metolachlor/atrazine + mesotrione fb glyphosate(PRE $\mathrm{fb}$ LPOST). Application doses selected were based on the manufacturers recommended dose for each herbicide in Ontario and are listed in Table 4.

All plots were $3 \mathrm{~m}$ (4 corn rows spaced $75 \mathrm{~cm}$ apart) wide and $8 \mathrm{~m}$ long at Harrow and Ridgetown and $10 \mathrm{~m}$ long at Exeter. Glyphosate-resistant corn hybrids were seeded at a density of 80000 seeds ha $^{-1}$. Herbicides were applied using a $\mathrm{CO}_{2}$-pressurized sprayer calibrated to deliver $222 \mathrm{~L} \mathrm{ha}^{-1}$ aqueous solution at $210 \mathrm{kPa}$ at Harrow, $200 \mathrm{~L} \mathrm{ha}^{-1}$ aqueous solution at $240 \mathrm{kPa}$ at Exeter and $200 \mathrm{~L} \mathrm{ha}^{-1}$ aqueous solution at $200 \mathrm{kPa}$ at Ridgetown. The boom was $1.5 \mathrm{~m}$ wide with four ultra-low drift nozzles (ULD120-02, Hypro, New Brighton, MN) spaced $50 \mathrm{~cm}$ apart. PRE treatments were applied 0-7 days after seeding, EPOST treatments were applied at 3-4 corn leaf stage and the LPOST treatments were applied at 6-8 corn leaf stage.

Crop injury was evaluated visually 2 and 3 weeks after emergence (WAE), using a scale of 0 to $100 \%$ where a rating of 0 was defined as no visible plant injury and a rating of 100 was defined as plant death. Percent weed control was visually assessed 4 and 8 weeks after the LPOST herbicide application (WAA) using a scale of 0 to $100 \%$ where a rating of 0 was defined as no weed control and a rating of 100 was defined as complete control. Weed density and biomass (dry weight) were evaluated at approximately $3 \mathrm{WAE}$ (prior to LPOST glyphosate application) by counting and cutting plants at the soil surface in two $0.5 \mathrm{~m}^{2}$ quadrats per plot and separating by species. Plants were dried at $60{ }^{\circ} \mathrm{C}$ to constant moisture and then weighed. Corn was mechanically harvested at physiological maturity using a plot combine at all sites. Corn yields were adjusted to a $15.5 \%$ moisture level.

\section{Statistical Analyses}

All data were subjected to analysis of variance and analyzed using the PROC MIXED procedure in SAS statistical software (Version 9.2. SAS Institute, Inc., Box 8000, SAS Circle, Cary, NC 27512). Variances were partitioned into the fixed effect of herbicide treatment and into the random effects of environment (year and location). When there were no significant interactions between environment and treatment the data were pooled and averaged. The assumptions of the variance analysis were tested by ensuring that the residuals were random, homogeneous, with a normal distribution about a mean of zero using residual plots and a Shapiro-Wilk normality test. All percentage data required an arcsine square root transformation. Yield data did not require transformation. All percentage data presented in tables are on the backtransformed scale. Treatment means were separated at the $5 \%$ level of significance using Fisher's Protected LSD test.

\section{Environmental Impact}

The environmental risk for each herbicide treatment was determined using published EIQ values for all active ingredients (a.i.) [22]. The environmental impact of each treatment was calculated by multiplying herbicide EIQ by the amount applied in $\mathrm{kg}$ ai (ae) $\mathrm{ha}^{-1}$. For herbicide products and/or tank mixes that contain more than one active ingredient, the EI was calculated by summing EIQs at the appropriate proportion.

\section{Profitability Analysis}

The profitability analysis is based on the level of profit margins over weed control costs, measured as gross income less herbicide and application costs. Gross income for each treatment was calculated as the yield multiplied the cash price of corn in Chatham, ON as of October 1 of each year and the herbicide costs for each treatment are based on the herbicide prices reported by AGRIS (AGRIS Co-operative Ltd., 835 Park Avenue West, Chatham, ON N7M 5J6, Canada). Application costs are determined based on cost of pro- 
duction data reported by the Ontario Ministry of Agriculture, Food and Rural Affairs (Field Crop Budgets, Publication 60, updated annually; Ontario Ministry of Agriculture, Food and Rural Affairs, 1 Stone Road West, Guelph, ON N1G 4Y2, Canada). All other costs of production are assumed to be constant across treatments, thus they are not considered in the analysis. Pairwise comparisons were made between treatments to test for significant differences in average profit margins between treatments. These pairwise comparisons are made across all locations and years as well as for each location in each year.

\section{RESULTS AND DISCUSSION}

\section{Weed Control}

The dominant weed species in this study were velvetleaf (Abutilon theophrasti Medic.; ABUTH), green pigweed (Amaranthus powellii L.; AMAPO), common ragweed (Ambrosia artemisiifolia L.; AMBEL), common lamb's-quarters (Chenopdium album L.; CHEAL), lady's thumb (Polygonum persicaria L.; POLPE), barnyard grass (Echinochloa crusgalli; ECHCG), and green foxtail (Setaria viridis L.; SETVI). There was no significant interaction between environments and treatments, therefore these data were pooled and averaged over environments.

\section{Weed Control Prior to In-Crop Glyphosate Application}

At approximately 3 to $4 \mathrm{WAE}$, one EPOST application of glyphosate prior to the LPOST application of glyphosate controlled ABUTH 74\%, AMAPO 93\%, AMBEL 82\%, CHEAL $81 \%$, POLPE $73 \%$, ECHCG $72 \%$, and SETVI $88 \%$
(Table 1). All of PRE herbicides evaluated provided equivalent control of AMAPO and CHEAL 3 to $4 \mathrm{WAE}$ prior to the LPOST application of glyphosate. The PRE application of atrazine provided the poorest control of ABUTH (44 to 52\%) while mesotrione provided the best control of ABUTH (76\%). The PRE application of atrazine provided the poorest control of AMBEL (62 to 68\%) and ECHCG (39\%) while all the remaining herbicides provided equivalent control of these weeds species. The PRE application of pendimethalin plus atrazine provided the poorest control of POLPE (74\%) while all the remaining herbicides provided equivalent control of POLPE. Control of SETVI was the poorest with atrazine (42\%) and dicamba/atrazine (45\%) (Table 1).

\section{Weed Density Prior to In-Crop Glyphosate Application}

One early postemergence application of glyphosate reduced density of ABUTH $86 \%$, AMAPO $76 \%$, AMBEL $73 \%$, CHEAL $63 \%$, POLPE $71 \%$, ECHCG $85 \%$, and SETVI $81 \%$ compared to the weedy check (Table 2). The PRE herbicides reduced the density of AMAPO (94-97\%), CHEAL (83-98\%) and POLPE (76-100\%) equivalently. The PRE application mesotrione, saflufenacil, isoxaflutole and flumetsulam reduced ABUTH density the most. The PRE application of pendimethalin plus atrazine, atrazine and smetolachlor/atrazine reduced AMBEL density the least. The PRE application atrazine and dicamba and Pendimethalin + atrazine and atrazine reduced ECHCG density least and there was no difference in density among the other herbicides evaluated. The PRE application atrazine and dicamba reduced SETVI density least (Table 2).

Table 1. Mean Control (\%) of Various Weeds in Response to Weed Management Strategies 4 Weeks After Emergence (Prior to the in-Crop Application of Glyphosate) in Twelve Field Trials Conducted at Exeter, Harrow and Ridgetown, ON, Canada During 2010 to $2012^{z, y}$

\begin{tabular}{|c|c|c|c|c|c|c|c|}
\hline 3 & $74 \mathrm{ab}$ & $93 a$ & $82 a$ & $81 \mathrm{a}$ & $73 b$ & $72 a$ & $88 \mathrm{a}$ \\
\hline 7 & $52 \mathrm{c}$ & $75 a$ & $62 \mathrm{~b}$ & $75 a$ & $74 \mathrm{~b}$ & $42 b$ & $67 b$ \\
\hline 10 & $65 \mathrm{~b}$ & $79 a$ & $77 a$ & $78 \mathrm{a}$ & $90 \mathrm{a}$ & $52 \mathrm{~b}$ & $68 \mathrm{~b}$ \\
\hline 11 & $66 \mathrm{~b}$ & $79 a$ & $74 \mathrm{ab}$ & $73 a$ & $90 \mathrm{a}$ & $59 \mathrm{~b}$ & $74 \mathrm{~b}$ \\
\hline 12 & $64 \mathrm{~b}$ & $79 a$ & $76 a$ & $75 a$ & $92 a$ & $46 \mathrm{~b}$ & $75 b$ \\
\hline 16 & $76 a$ & $87 a$ & $83 a$ & $76 a$ & $93 a$ & $53 b$ & $68 b$ \\
\hline
\end{tabular}

${ }^{\mathrm{z}}$ Abbreviations: ABUTH, velvetleaf; AMAPO, green pigweed; AMBEL, common ragweed; CHEAL, common lambsquarters; POLPE, lady's thumb; ECHCG, barnyardgrass; and SETVI, green foxtail.

${ }^{y}$ Data were averaged for environments. Means followed by the same letter within a column are not significantly different according to Fisher's Protected LSD (P $<0.05$ ). Treatment 4 was removed as there was no herbicide applied at this point. Treatment 5 was also removed since at this point in the season it was just a repeat of Treatment 3 . 
Table 2. Mean Density (no. $\left.\mathrm{m}^{-2}\right)$ and Biomass $\left(\mathrm{g} \mathrm{m}^{-2}\right)$ of Various Weeds in Response to Weed Management Strategies 4 Weeks After Emergence (Prior to the in-Crop Application of Glyphosate) in Twelve Field Trials Conducted at Exeter, Harrow and Ridgetown, ON, Canada During 2010 to $2012^{z, y}$

\begin{tabular}{|c|c|c|c|c|c|c|c|c|c|c|c|c|c|c|}
\hline Treatment & \multicolumn{2}{|c|}{ ABUTH $^{\mathbf{z}}$} & \multicolumn{2}{|c|}{ AMAPO $^{\mathbf{Z}}$} & \multicolumn{2}{|c|}{ AMBEL $^{\mathrm{z}}$} & \multicolumn{2}{|c|}{ CHEAL $^{\mathrm{z}}$} & \multicolumn{2}{|c|}{ POLPE $^{\mathrm{Z}}$} & \multicolumn{2}{|c|}{ ECHCG $^{\mathrm{z}}$} & \multicolumn{2}{|c|}{ SETVI $^{z}$} \\
\hline & no. $\mathrm{m}^{-2}$ & $\mathrm{~g} \mathrm{~m}^{-2}$ & no. $\mathrm{m}^{-2}$ & $\mathrm{~g} / \mathrm{m}^{2}$ & no. $m^{-2}$ & $\mathrm{~g} \mathrm{~m}^{-2}$ & no. $\mathrm{m}^{-2}$ & $\mathrm{~g} \mathrm{~m}^{-2}$ & no. $\mathrm{m}^{-2}$ & $\mathrm{~g} \mathrm{~m}^{-2}$ & no. $\mathrm{m}^{-2}$ & $\mathrm{~g} \mathrm{~m}^{-2}$ & no. $m^{-2}$ & $\mathrm{~g} \mathrm{~m}^{-2}$ \\
\hline 1 weedy & $21 \mathrm{a}$ & $3.8 \mathrm{a}$ & $34 \mathrm{a}$ & 19.6a & $26 a$ & $29.9 \mathrm{a}$ & $54 \mathrm{a}$ & $14.5 \mathrm{a}$ & $17 \mathrm{a}$ & $14.9 \mathrm{a}$ & $20 \mathrm{a}$ & $7.3 \mathrm{~b}$ & $122 \mathrm{a}$ & $7.3 \mathrm{a}$ \\
\hline 6 & $13 b$ & $2.6 \mathrm{a}$ & $2 \mathrm{c}$ & $1 \mathrm{~b}$ & $4 \mathrm{~cd}$ & $0.14 \mathrm{~b}$ & $2 b$ & $1.1 \mathrm{~b}$ & $1 \mathrm{~b}$ & $0.1 \mathrm{~b}$ & $28 \mathrm{a}$ & $17.9 \mathrm{a}$ & $54 \mathrm{~b}$ & $1.2 \mathrm{~b}$ \\
\hline 7 & $16 \mathrm{a}$ & $2.7 \mathrm{a}$ & $1 \mathrm{c}$ & $0.18 \mathrm{~b}$ & $11 \mathrm{~b}$ & $12.4 \mathrm{a}$ & $3 b$ & $0.69 \mathrm{~b}$ & $4 \mathrm{~b}$ & $5.5 \mathrm{~b}$ & $21 \mathrm{a}$ & $5.9 \mathrm{~b}$ & $12 \mathrm{c}$ & $0.67 \mathrm{~b}$ \\
\hline 8 & $11 \mathrm{~b}$ & $1.8 \mathrm{a}$ & $2 \mathrm{c}$ & $1.6 \mathrm{~b}$ & $3 \mathrm{~cd}$ & $0.35 b$ & $1 b$ & $0.84 \mathrm{~b}$ & $1 \mathrm{~b}$ & $0.1 \mathrm{~b}$ & $8 b$ & $5.6 \mathrm{~b}$ & $14 \mathrm{c}$ & $0.16 \mathrm{~b}$ \\
\hline 9 & $4 \mathrm{c}$ & $1.3 \mathrm{a}$ & $1 \mathrm{c}$ & $0.7 \mathrm{~b}$ & $1 d$ & $1.7 \mathrm{~b}$ & $3 b$ & $1.9 \mathrm{~b}$ & $0 \mathrm{~b}$ & $0 \mathrm{~b}$ & $6 \mathrm{~b}$ & $2.0 \mathrm{~b}$ & $3 \mathrm{~d}$ & $0.16 \mathrm{~b}$ \\
\hline 12 & $8 \mathrm{bc}$ & $1.9 \mathrm{a}$ & $2 \mathrm{c}$ & $1 \mathrm{~b}$ & $4 \mathrm{~cd}$ & $1.3 \mathrm{~b}$ & $6 \mathrm{~b}$ & $2.4 \mathrm{~b}$ & $0 \mathrm{~b}$ & $0 \mathrm{~b}$ & $6 \mathrm{~b}$ & $5.2 \mathrm{~b}$ & $0 \mathrm{~d}$ & $0 \mathrm{~b}$ \\
\hline 13 & $21 \mathrm{a}$ & $3.5 \mathrm{a}$ & $1 \mathrm{c}$ & $0.7 \mathrm{~b}$ & $4 \mathrm{~cd}$ & $0.45 b$ & $4 \mathrm{~b}$ & $2.1 \mathrm{~b}$ & $1 \mathrm{~b}$ & $1.3 \mathrm{~b}$ & $6 \mathrm{~b}$ & $1.1 \mathrm{~b}$ & $2 \mathrm{~d}$ & $0.07 \mathrm{~b}$ \\
\hline 14 & $13 b$ & $3.4 \mathrm{a}$ & $1 \mathrm{c}$ & $0.4 \mathrm{~b}$ & $7 \mathrm{c}$ & $10.4 \mathrm{ab}$ & $3 \mathrm{~b}$ & $0.9 \mathrm{~b}$ & $2 \mathrm{~b}$ & $2.0 \mathrm{~b}$ & $14 \mathrm{a}$ & $4.7 \mathrm{~b}$ & $44 \mathrm{~b}$ & $1.1 \mathrm{~b}$ \\
\hline 15 & $30 \mathrm{a}$ & $4.7 \mathrm{a}$ & $1 \mathrm{c}$ & $0.3 \mathrm{~b}$ & $9 \mathrm{bc}$ & $7.4 \mathrm{~b}$ & $9 \mathrm{~b}$ & $3.2 \mathrm{~b}$ & $2 \mathrm{~b}$ & $4.7 \mathrm{~b}$ & $4 \mathrm{~b}$ & $3.6 \mathrm{~b}$ & $5 \mathrm{~d}$ & $0.25 \mathrm{~b}$ \\
\hline 16 & $2 \mathrm{c}$ & $0.9 \mathrm{a}$ & $1 \mathrm{c}$ & $0.4 \mathrm{~b}$ & $1 \mathrm{~d}$ & $1.3 \mathrm{~b}$ & $6 \mathrm{~b}$ & $2.3 \mathrm{~b}$ & $0 \mathrm{~b}$ & $0 \mathrm{~b}$ & $3 b$ & $1.7 \mathrm{~b}$ & $3 \mathrm{~d}$ & $0.07 \mathrm{~b}$ \\
\hline
\end{tabular}

${ }^{z}$ Abbreviations: ABUTH, velvetleaf; AMAPO, green pigweed; AMBEL, common ragweed; CHEAL, common lambsquarters; POLPE, lady's thumb; ECHCG, barnyardgrass; and SETVI, green foxtail.

${ }^{y}$ Data were averaged for environments. Means followed by the same letter within a column are not significantly different according to Fisher's Protected LSD (P $<0.05$ ). Treatment 4 was removed as there was no herbicide applied at this point. Treatment 5 was also removed since at this point in the season it was just a repeat of Treatment 3.

\section{Weed Biomass Prior to In-Crop Glyphosate Application}

One early postemergence application of glyphosate reduced biomass of ABUTH 66\%, AMAPO $93 \%$, AMBEL $39 \%$, CHEAL $73 \%$, POLPE $61 \%$, ECHCG $73 \%$, and SETVI $98 \%$ compared to the weedy check however, results were not always statistically significant (Table 2). The PRE herbicides reduced the density of ABUTH, AMAPO, CHEAL, POLPE and SETVI equivalently. Generally, the biomass of AMBEL was not reduced as much with atrazine and the biomass of ECHCG was decreased the least with dicamba/atrazine (Table 2).

\section{Weed Control after In-Crop Glyphosate Application}

Data for 4 and 8 WAA were similar; therefore only data for 8 WAA are presented (Table 3). One EPOST application of glyphosate controlled ABUTH 53\%, AMAPO 80\%, AMBEL $72 \%$, CHEAL $67 \%$, POLPE $83 \%$, ECHCG $49 \%$, and SETVI $56 \%$. One LPOST application of glyphosate provided control of ABUTH 82\%, AMAPO 97\%, AMBEL 85\%, CHEAL 93\%, POLPE 73\%, ECHCG 96\%, and SETVI 91\% which was greater than the EPOST application with the exception of POLPE which was reduced. The sequential application of glyphosate (EPOST fb LPOST) improved efficacy and controlled ABUTH 92\%, AMAPO 98\%, AMBEL 93\%, CHEAL 95\%, POLPE 93\%, ECHCG 97\%, and SETVI 92\%. The sequential application of a preemergence herbicide followed by an application of glyphosate LPOST controlled
ABUTH 91-98\%, AMAPO 99-100\%, AMBEL 95-98\%, CHEAL 97-99\%, POLPE 95-99\%, ECHCG 97-99\%, and SETVI $93-99 \%$ which was equivalent to the sequential application of glyphosate. Results are similar to other studies that have shown sequential in-crop applications of glyphosate or including a residual PRE herbicide with POST herbicides control weed escapes and late-emerging weeds in corn [5,6,15,17-19].

In other studies Stewart et al. [7] found 7-11\% lower redroot pigweed control with an EPOST application of glyphosate compared to a sequential application of glyphosate in corn. However, a sequential application of glyphosate did not improve redroot pigweed control in comparison to a single EPOST application in soybean [16]. Other studies have found that the sequential application of glyphosate or by following a PRE herbicide with a POST application of glyphosate effectively controls late-emerging weeds in glyphosate-resistant corn $[6,15,18]$. The sequential glyphosate applications also increased common lamb's-quarters control 5$9 \%$ in corn and $4-9 \%$ in soybean compared to a single application of glyphosate $[7,18]$. However, other studies have shown adequate season long control of common lamb'squarters with a single application of glyphosate under certain environmental conditions [16]. Gonzini et al. [18] found 13$22 \%$ and $17-27 \%$ increase in velvetleaf control compared to a single application of glyphosate when PRE herbicides were followed by glyphosate or sequential applications of 
Table 3. Mean control (\%) of various weeds in response to weed management strategies 8 WAA in twelve field trials conducted at Exeter, Harrow and Ridgetown, ON, Canada during 2010 to 2012 (data averaged over environments)

\begin{tabular}{|c|c|c|c|c|c|c|c|}
\hline 3 & $53 \mathrm{c}$ & $80 \mathrm{~b}$ & $72 b$ & $67 b$ & $83 b$ & $49 \mathrm{~b}$ & $56 \mathrm{~b}$ \\
\hline 5 & $92 \mathrm{a}$ & $98 \mathrm{a}$ & $93 a$ & $95 \mathrm{a}$ & $93 a$ & $97 \mathrm{a}$ & $92 \mathrm{a}$ \\
\hline 8 & $91 \mathrm{a}$ & $99 \mathrm{a}$ & $97 \mathrm{a}$ & $99 \mathrm{a}$ & $99 \mathrm{a}$ & $98 \mathrm{a}$ & $97 \mathrm{a}$ \\
\hline 9 & $95 \mathrm{a}$ & $100 \mathrm{a}$ & $98 \mathrm{a}$ & $97 a$ & $97 \mathrm{a}$ & $99 a$ & $96 a$ \\
\hline 10 & $98 \mathrm{a}$ & $100 \mathrm{a}$ & $98 \mathrm{a}$ & $99 a$ & $98 \mathrm{a}$ & $99 a$ & $97 \mathrm{a}$ \\
\hline 14 & $92 \mathrm{a}$ & $99 \mathrm{a}$ & $95 \mathrm{a}$ & $97 \mathrm{a}$ & $98 \mathrm{a}$ & $98 \mathrm{a}$ & $93 a$ \\
\hline 15 & $91 \mathrm{a}$ & $100 \mathrm{a}$ & $97 a$ & $98 \mathrm{a}$ & $97 \mathrm{a}$ & $99 \mathrm{a}$ & $98 \mathrm{a}$ \\
\hline 16 & $96 a$ & $100 \mathrm{a}$ & $97 \mathrm{a}$ & $98 \mathrm{a}$ & $98 \mathrm{a}$ & $98 \mathrm{a}$ & $98 \mathrm{a}$ \\
\hline
\end{tabular}

${ }^{\mathrm{z}}$ Abbreviations: ABUTH, velvetleaf; AMAPO, green pigweed; AMBEL, common ragweed; CHEAL, common lambsquarters; POLPE, lady's thumb; ECHCG, barnyardgrass; and SETVI, green foxtail.

${ }^{\mathrm{y}}$ Data were averaged for environments. Means followed by the same letter within a column are not significantly different according to Fisher's Protected LSD (P $<0.05$ ).

glyphosate were applied, respectively. Similarly, giant foxtail control improved $2-15 \%$ with sequential applications of glyphosate POST or PRE herbicides followed by a POST application of glyphosate compared to a single-pass application of glyphosate POST [18].

\section{Crop Injury and Yield}

No visible injury resulted from the herbicide treatments evaluated at 2 and 3 WAE (data not shown). Herbicide treatments increased corn yield 5.4 to $6.8 \mathrm{t} \mathrm{ha}^{-1}$ compared to the non-treated weedy control (Table 4). There was no difference in corn yield between glyphosate applied EPOST, LPOST and sequential glyphosate applications (EPOST fb LPOST). Yields generally tended to be higher with PRE herbicides $f b$ glyphosate LPOST compared to glyphosate applied alone EPOST or LPOST although results were not always statistically significant (Table 4). Higher yields can be attributed to increased weed control (Table 3). In other studies PRE herbicide (flufenacet + metribuzin) $f b$ glyphosate increased corn yield compared to the glyphosate alone which was attributed to early season weed control [6].

\section{Profitability Analysis}

Profitability analysis indicated that weeds decreased profit margin 1412 CAN $\$ \mathrm{ha}^{-1}$ compared to the weed-free control (Table 4). Herbicide treatments increased profit margin 1149 to 1343 CAN $\$$ ha $^{-1}$ compared to non-treated weedy control (Table 4). There was no significant difference in profit margin between glyphosate applied EPOST (2545 CAN $\left.\$ \mathrm{ha}^{-1}\right)$, LPOST (2605 CAN $\$ \mathrm{ha}^{-1}$ ) or sequential gly- phosate applications EPOST fb LPOST (2680 CAN\$ ha ${ }^{-1}$ ). The sequential application of dicamba/atrazine PRE fb glyphosate LPOST had a higher profit margin than glyphosate EPOST (2815 vs 2545 CAN\$ ha ${ }^{-1}$ ) and LPOST (2815 vs 2605 CAN $\$ \mathrm{ha}^{-1}$ ) but had no significant difference with the sequential application of glyphosate EPOST $\mathrm{fb}$ LPOST (Table 4). S-metolachlor + flumetsulam + clopyralid PRE fb glyphosate LPOST had the lowest profit margin (1149 CAN\$ $\mathrm{ha}^{-1}$ ) but the difference was only significant with dicamba/atrazine PRE fb glyphosate LPOST (2815 CAN\$ $\left.\mathrm{ha}^{-1}\right)$ and weed-free control (2785 CAN\$ ha $\left.{ }^{-1}\right)$. There was generally no other differences between weed management strategies in respect to profit margins. Overall, profit margin was equivalent regardless of the PRE herbicides used except for s-metolachlor + flumetsulam + clopyralid.

\section{Environmental Impact}

Among the herbicide treatments evaluated, glyphosate EPOST or LPOST applied alone had the lowest EI value of 13.8 (Table 5). As expected adding another active ingredient to the weed management strategy increased the EI. Among the sequential programs the environmental impact of applying glyphosate EPOST fb LPOST with the EI value of 27.6 was higher than EI of applying saflufenacil/dimethenamid-p, isoxaflutole + atrazine, and rimsulfuron $+\mathrm{s}$-metolachlor + dicamba PRE fb glyphosate LPOST with EI values of 20.2, 26.5, 26.3, respectively (Table 5). However, the EI of applying glyphosate EPOST fb LPOST with EI value of 27.6 was less than EI of applying dicamba/atrazine, pendimethalin + atrazine, pendimethalin + dicamba/atrazine, s-metolachlor/atrazine + flumetsulam, s-metolachlor + 
Table 4. Mean Corn Yield and Profit Margin of Weed Management Strategies Used at Twelve Field Trials Conducted in Exeter, Harrow, and Ridgetown, ON, Canada During 2010 to $2012^{z, y}$

\begin{tabular}{|c|c|c|c|c|c|}
\hline S.No. & Treatment & Timing & Herbicide Rate & Yield & Profit \\
\hline & & & $\left(\mathrm{g} \mathrm{ai} / \mathrm{ae} \mathrm{ha}^{-1}\right)$ & $\left(\mathrm{t} \mathrm{ha}^{-1}\right)$ & $\left(\mathrm{CAN} \$ \mathrm{ha}^{-1}\right)$ \\
\hline 1. & Weedy & & & $6.7 \mathrm{~d}$ & $1372.74 \mathrm{~d}$ \\
\hline 2. & Weed-free & & & $13.0 \mathrm{abc}$ & $2784.80 \mathrm{ab}$ \\
\hline 3. & Glyphosate (early) & EPOST $^{\mathrm{y}}$ & 900 & $12.1 \mathrm{c}$ & $2544.73 \mathrm{bc}$ \\
\hline 4. & Glyphosate (late) & LPOST $^{\mathrm{y}}$ & 900 & $12.3 \mathrm{bc}$ & $2604.81 \mathrm{abc}$ \\
\hline 5. & Glyphosate fb glyphosate & EPOST fb LPOST ${ }^{\mathrm{y}}$ & $900 \mathrm{fb} 900$ & $12.9 \mathrm{abc}$ & $2680.01 \mathrm{abc}$ \\
\hline 6. & Dicamba/atrazine fb glyphosate & PRE fb LPOST ${ }^{y}$ & $1000 \mathrm{fb} 900$ & $13.5 \mathrm{a}$ & $2815.46 \mathrm{a}$ \\
\hline 7. & Pendimethalin + atrazine fb glyphosate & PRE fb LPOST & $1000+1000 \mathrm{fb} 900$ & $13.1 \mathrm{ab}$ & $2715.56 \mathrm{abc}$ \\
\hline 8. & Pendimethalin + dicamba/atrazine fb glyphosate & PRE fb LPOST ${ }^{y}$ & $1000+1000 \mathrm{fb} 900$ & $13.1 \mathrm{ab}$ & $2677.62 \mathrm{abc}$ \\
\hline 9. & Saflufenacil/DMTA-p fb glyphosate & PRE fb LPOST & $490 \mathrm{fb} 900$ & $12.9 \mathrm{abc}$ & $2645.33 \mathrm{abc}$ \\
\hline 10. & Isoxaflutole + AE0001789 + atrazine fb glyphosate & PRE fb LPOST ${ }^{y}$ & $52.5+500 \mathrm{fb} 900$ & $12.8 \mathrm{abc}$ & $2662.22 \mathrm{abc}$ \\
\hline 11. & S-metolachlor/atrazine + flumetsulam fb glyphosate & PRE fb LPOST ${ }^{y}$ & $1800+50 \mathrm{fb} 900$ & $12.7 \mathrm{abc}$ & $2613.78 \mathrm{abc}$ \\
\hline 12. & S-metolachlor + flumetsulam + clopyralid fb glyphosate & PRE fb LPOST ${ }^{y}$ & $1600+50+135 \mathrm{fb} 900$ & $12.8 \mathrm{abc}$ & $2521.92 \mathrm{c}$ \\
\hline 13. & Rimsulfuron + s-metolachlor + dicamba fb glyphosate & PRE fb LPOST ${ }^{\mathrm{y}}$ & $15+342+180 \mathrm{fb} 900$ & $13.2 \mathrm{ab}$ & $2683.84 \mathrm{abc}$ \\
\hline 14. & Atrazine fb glyphosate & PRE fb LPOST ${ }^{\mathrm{y}}$ & $1500 \mathrm{fb} 900$ & $12.9 \mathrm{abc}$ & $2690.49 \mathrm{abc}$ \\
\hline 15. & S-metolachlor/atrazine fb glyphosate & PRE fb LPOST ${ }^{y}$ & $1800 \mathrm{fb} 900$ & $12.7 \mathrm{abc}$ & $2623.70 \mathrm{abc}$ \\
\hline 16. & S-metolachlor/atrazine + mesotrione fb glyphosate & PRE fb LPOST ${ }^{\mathrm{y}}$ & $1800+70 \mathrm{fb} 900$ & $13.2 \mathrm{ab}$ & $2687.54 \mathrm{abc}$ \\
\hline
\end{tabular}

${ }^{\mathrm{z}}$ Data were averaged for environments. Means followed by the same letter within a column are not significantly different according to Fisher's Protected LSD (P $<0.05$ ).

${ }^{\mathrm{y}}$ Abbreviations: EPOST, early postemergence; LPOST, late postemergence; fb, followed by.

Table 5. Environmental Impact Quotient (EIQ) and Environmental Impact (EI) of Weed Management Strategies Used at Twelve Field Trials Conducted at Exeter, Harrow, and Ridgetown, ON During 2010 to $2012^{z}$

\begin{tabular}{|c|c|c|c|c|c|}
\hline S.No. & Active ingredient(s) & Timing & Individual EIQ values $^{y}$ & $\begin{array}{c}\text { Herbicide Rate } \\
\text { g ai/ae ha }{ }^{-1}\end{array}$ & $\mathbf{E I}^{\mathbf{x}}$ \\
\hline 1. & Weedy check & & & & \\
\hline 2. & Weed free check & & & & \\
\hline 3. & Glyphosate & EPOST $^{z}$ & 15.3 & 900 & 13.8 \\
\hline 4. & Glyphosate & $\mathrm{LPOST}^{\mathrm{z}}$ & 15.3 & 900 & 13.8 \\
\hline 5. & Glyphosate fb glyphosate & EPOST fb LPOST ${ }^{z}$ & $15.3 \mathrm{fb} 15.3$ & $900 \mathrm{fb} 900$ & 27.6 \\
\hline 6. & Dicamba/atrazine fb glyphosate & PRE fb LPOST ${ }^{z}$ & $26.3 / 22.9 \mathrm{fb} 15.3$ & $1000 \mathrm{fb} 900$ & 37.8 \\
\hline 7. & Pendimethalin+atrazine fb glyphosate & PRE fb LPOST ${ }^{z}$ & $30.2+22.9 \mathrm{fb} 15.3$ & $1000+1000 \mathrm{fb} 900$ & 66.9 \\
\hline 8. & Pendimethalin+dicamba/atrazine fb glyphosate & PRE fb LPOST ${ }^{z}$ & $30.2+26.3 / 22.9 \mathrm{fb} 15.3$ & $1000+1000 \mathrm{fb} 900$ & 68.0 \\
\hline 9. & Saflufenacil/dimethenamid-p fb glyphosate & PRE fb LPOST ${ }^{z}$ & $22.3 / 12.0 \mathrm{fb} 15.3$ & $490 \mathrm{fb} 900$ & 20.2 \\
\hline 10. & Isoxaflutole+atrazine fb glyphosate & PRE fb LPOST ${ }^{z}$ & $24.0+22.9 \mathrm{fb} 15.3$ & $52.5+500 \mathrm{fb} 900$ & 26.5 \\
\hline 11. & S-metolachlor/atrazine+flumetsulam fb glyphosate & PRE fb LPOST ${ }^{z}$ & $22.0 / 22.9+15.6 \mathrm{fb} 15.3$ & $1800+50 \mathrm{fb} 900$ & 54.9 \\
\hline 12. & S-metolachlor+flumetsulam+clopyralid fb glyphosate & PRE fb LPOST ${ }^{z}$ & $22.0+15.6+18.1 \mathrm{fb} 15.3$ & $1600+50+135 \mathrm{fb} 900$ & 52.2 \\
\hline 13. & Rimsulfuron + s-metolachlor+dicamba fb glyphosate & PRE fb LPOST ${ }^{z}$ & $15.8+22.0+26.3 \mathrm{fb} 15.3$ & $15+342+180 \mathrm{fb} 900$ & 26.3 \\
\hline
\end{tabular}


(Table 5) contd....

\begin{tabular}{|c|c|c|c|c|c|}
\hline 15. & S-metolachlor/atrazine fb glyphosate & PRE fb LPOST ${ }^{z}$ & $22.0 / 22.9 \mathrm{fb} 15.3$ & $1800 \mathrm{fb} 900$ & 54.1 \\
\hline 16. & S-metolachlor/atrazine+mesotrione fb glyphosate & PRE fb LPOST ${ }^{z}$ & $22.0 / 22.9+18.7 \mathrm{fb} 15.3$ & $1800+70 \mathrm{fb} 900$ & 55.4 \\
\hline
\end{tabular}

${ }^{\mathrm{z}}$ Abbreviations: EPOST, early postemergence; LPOST, late postemergence; fb, followed by; EIQ, environmental impact quotient; EI, environmental impact.

${ }^{y}$ EIQ values for each a.i. obtained from Kovach et al. (1999 updated 2010)

${ }^{\mathrm{x}}$ EI values for products with more than one a.i. were obtained by summing the relative proportion of each a.i.

flumetsulam + clopyralid, atrazine, s-metolachlor/atrazine, and s-metolachlor/atrazine + mesotrione PRE fb glyphosate LPOST with EI values of $37.8,66.9,68.8,54.9,52.2,48.2$, 54.1 , and 55.4, respectively (Table 5). Thus, the addition of the saflufenacil/dimethenamid-p, isoxaflutole + atrazine and rimsulfuron $+\mathrm{s}-$ metolachlor + dicamba applied PRE fb glyphosate applied LPOST to glyphosate-resistant corn production is strongly recommended based on equivalent environmental risk as well as resistance management.

\section{CONCLUSIONS}

Based on results of this study, herbicide efficacy is weed species specific and the PRE herbicide of choice is dependent on historical field records. All PRE herbicides evaluated provided excellent control of green pigweed, lamb's-quarters and lady'sthumb. Atrazine is weak on velvetleaf and common ragweed. Dicamba and atrazine were weak on barnyard grass and green foxtail. Glyphosate was the great equalizer as the control of all weeds 8 WAA was equivalent regardless of the PRE herbicide applied. Corn yield was equivalent regardless of the PRE herbicide applied. Net returns were equivalent regardless of the PRE herbicide applied with the exception of s-metolachlor + flumetsulam + clopyralid. The Environmental Impact is influenced by herbicide choice. The single application of glyphosate had the lowest EI. The EI of some PRE/POST programs were equivalent (or less) than two applications of glyphosate. However, the EI of some PRE/POST programs had a greater EI such as pendimethalin, s-metolachlor and atrazine. This study concludes that a sequential application of glyphosate or a two-pass program of a preemergence herbicide followed by glyphosate LPOST provides the most efficacious and profitable weed management programs in glyphosate-resistant corn. These two-pass programs have the potential to reduce selection pressure and have glyphosate stewardship benefits.

\section{CONFLICT OF INTEREST}

The author(s) confirm that this article content has no conflicts of interest.

\section{ACKNOWLEDGEMENT}

The authors would like to acknowledge the technical assistance of Lynette Brown, Todd Cowan, Elaine Lepp, Cara McCreary and Christy Shropshire.

\section{REFERENCES}

[1] Kulasekera K. Grain Corn: Area and Production, by County. 2012. Available at: http://www.omafra.gov.on.ca/english/stats/crops/ ctygrcorn11.htm [Accessed: 18 Dec. 2012].
[2] Kulasekera K. Statistical Summary of Ontario Agriculture. 2012. Available at: http://www.omafra.gov.on.ca/english/stats/ agriculture summary.htm\#commodities. [Accessed: 18 Dec. 2012].

[3] Sikkema P.H., Soltani N. Herbicide-resistant crops in eastern Canada. In: Gulden RH, Swanton CJ, Eds. The first decade of herbicide-resistant crops in Canada. Topics in Canadian Weed Science. vol 4. Sainte Anne de Bellevue, Quebec: Canadian Weed Science Society- Societe Canadienne de malherbologie. 2007; pp. 3-13.

[4] Sikkema PH, Robinson DE, Tardif FJ, Lawton MB, Soltani N. Discovery of Glyphosate-Resistant Weeds in Ontario, Canada Distribution plus Control. Global Herbicide Resistant Challenge Conference, Perth, Australia. 2013.

[5] Barnes JW, Oliver LR. Cloransulam antagonizes annual grass control with aryloxyphenoxypropionate graminicides but not cyclohexanediones. Weed Technol 2004; 18: 763-72.

[6] Nurse RE, Swanton CJ, Tardif F, Sikkema PH. Weed control and yield are improved when glyphosate is preceded by a residual herbicide in glyphosate-tolerant maize (Zea mays). Crop Prot 2006; 25: 1174-9.

[7] Stewart CL, Soltani N, Nurse RE, Hamill AS, Sikkema PH. Precipitation influences pre- and postemergence herbicide efficacy in corn. Am J Plant Sci 2012; 3: 1193-204.

[8] Young BG. Changes in herbicide use patterns and production practices resulting from glyphosate-resistant crops. Weed Technol 2006; 20: 301-7.

[9] Heap I. The International Survey of Herbicide Resistant Weeds. 2009; Available at: http://www.weedscience.org. [Accessed: April 25, 2013].

[10] Vink JP, Soltani N, Robinson DE, et al. Occurrence and distribution of glyphosate-resistant giant ragweed (Ambrosia trifida L.) in southwestern Ontario. Can J Plant Sci 2012; 92: 533-9.

[11] Nelson KA. Glyphosate application timings in twin- and single-row corn and soybean spacings. Weed Technol 2007; 21: 186-90.

[12] Gower SA, Loux MM, Cardina J, Harrison SK. Effect of planting date, residual herbicide, and postemergence application timing on weed control and grain yield in glyphosate-resistant corn (Zea mays). Weed Technol 2002; 16: 488-94.

[13] Hartzler B. Is one-pass weed control a realistic goal? USA: Department of Agronomy, Iowa State University Extension Agronomy. 1996; p. 3.

[14] Loux MM, Dobbels AF, Johnson WG, et al. Weed control guide for Ohio and Indiana. Extension Bulletin 789/ Purdue Extension Pub No. WS16. USA: Ohio State University 2008; p. 201.

[15] Payne SA, Oliver LR. Weed control programs in drilled glyphosate-resistant soybean. Weed Technol 2000; 14: 413-22.

[16] Stewart CL, Nurse RE, Hamill AS, Sikkema PH. Environment and soil conditions influence pre- and postemergence herbicide efficacy in soybean. Weed Technol 2010; 24: 234-43.

[17] Corbett JL, Askew SD, Thomas WE, Wilcut JW. Weed efficacy evaluations for bromoxynil, glufosinate, glyphosate, pyrithiobac, and sulfosate. Weed Technol 2004; 18: 443-53.

[18] Gonzini LC, Hart SE, Wax LM. Herbicide combinations for weed management in glyphosate-resistant soybean (Glycine max). Weed Technol 1999; 13: 354-60.

[19] Nurse RE, Hamill AS, Swanton CJ, et al. Is the application of a residual herbicide required prior to glyphosate application in no-till glyphosate-tolerant soybean (Glycine max)? Crop Prot 2007, 26: 484-9. 
[20] Brookes G, Barfoot P. The global income and production effects of genetically modified (GM) crops 1996-2011. In: GM Crops and Food Biotechnology in Agriculture and Food Chain 2013; vol. 4(1), pp. 74-81.

[21] Kovach J, Petzoldt C, Degni J, Tette J. A method to measure the environmental impact of pesticides. NY Food Life Sci Bull 1992; 139:139-46.

[22] Kovach J, Petzoldt C, Degni J, Tette J. A method to measure the environmental impact of pesticides. In: Table 2. List of Pesticides. 1999; 7. Available at: http://www.nysipm.cornell.edu/ publications/eiq/. [Accessed: 22 Nov. 2012].

[23] Kovach J, Petzoldt C, Degni J, Tette J. Table 2. List of pesticides. 2012; Available at: http://www.nysipm.cornell.edu/publications/ eiq/equation.asp. [Accessed: December, 2012].
[24] Fernandez-Cornejo J. Environmental and economic consequences adoption: IPM in viticulture. J Agric Econ 1998; 18: 145-55.

[25] Edwards-Jones G, Howells O. The origin and hazard of inputs to crop protection in organic farming systems: are they sustainable? J Agric Syst 2001; 67: 31-47.

[26] Ziegler CR, Donahue DW, Drummond FA, Smith SN. The ecological economics of insecticide use associated with the Maine potato industry based on a producer survey. Am J Altern Agric 2002; 17: $159-66$.

[27] Bues R, Dadomo M, Lyannaz JP, et al. Evaluation of the environmental impact of the pesticides applied in processing tomato cropping. Acta Hortic 2003; 613: 255-8.

[28] Brimner TA, Gallivan GJ, Stephenson GR. Influence of herbicideresistant canola on the environmental impact of weed management Pest Manag Sci 2005; 61: 47-52.

Received: June 30, 2013

Revised: August 23, 2013

Accepted: August 23, 2013

(C) Soltani et al.; Licensee Bentham Open.

This is an open access article licensed under the terms of the Creative Commons Attribution Non-Commercial License (http://creativecommons.org/licenses/by-nc/3.0/) which permits unrestricted, non-commercial use, distribution and reproduction in any medium, provided the work is properly cited. 